Open Access

\title{
Student customized creative education model based on open innovation
}

\author{
Sun ah Kim ${ }^{1}$, Hyo yun Ryoo ${ }^{2^{*}}$ and Hee joo $\mathrm{Ahn}^{3}$
}

\author{
* Correspondence: \\ hirhy1212@hotmail.com \\ ${ }^{2}$ Kumoh National Institute of \\ Technology, Republic of Korea, \\ \#544, Global Building, 61 Daehak-ro, \\ Gumi, Gyeong-Buk 730-701, South \\ Korea \\ Full list of author information is \\ available at the end of the article
}

\begin{abstract}
As the creative economy has developed, the university has been given an important role of nurturing creative talents that companies desire to have. The most important objective in creative education is to provide a support system and a good environment for fostering creativity. This will help students in obtaining results and profits through experimenting as well as gaining experience in each step of the process in performing innovation by developing their ideas through utilizing self-directed information and knowledge. There are various creative economy-related businesses being conducted in Korea, which have been supported by the government since 2008, the supporting environment has been constructed to utilize the internal and external systems of universities. However, there are a number of cases where supporting projects that are possible to utilize are overlapping each other or support for projects is not available, as these sorts of supporting systems are designed according to the purpose and drawing performances for each business. For this, creating a "student customized innovation model" has been attempted by linking internal and external support for universities with a process of steps from design thinking to commercialization. The education model in universities should be established by balancing the roles and needs of enterprises, universities, and governments. An open innovation based system should be built for students who are being nurtured the university. The research method for this is as follows: First, the research aim was determined by considering the relationship between creative economy and the concept of open innovation. Second, a new model was developed by analyzing and doing case investigation of university convergence education programs that nurtured creativity. Third, this proposed model (CHEESE program (CHEESE Program stands for Creativity Human Emotional Experience Solution Evaluation)) was customized and designed based on the linkages between the creative education programs and open-innovation. Then, the outcomes from the project's three years test run were analyzed and organized. The development of the model was intended for design-engineering students based on integrating design-engineering thinking and activities in the process of innovation. The main objective of this study was to create a model (CHEESE program) based on the needs-centered activities that students wanted. This model has been restructured by linking the model with internal and external supporting projects of the university. The model has achieved continuous growth for 3 years and the performance has been improved in various aspects, such as patents, competition awards, and exhibition presentations. This project has drawn meaningful results in terms of experiencing the whole process of innovation, from the stage of determining an idea to making a prototype and commercializing it thorough exchanges with the internal and external systems of the university.
\end{abstract}

Keywords: Open Innovation, Creative education, Student customized 


\section{Introduction}

In his book The Creative Economy, the British business strategist John Howkins (2002) predicted that creativity will invigorate the manufacturing, service, retail, and entertainment industries beyond the deficient development of information and software. In the case of Korea, the country has been industrialized within merely half a century, and has maintained economic growth by developing IT and digital-based knowledge and information with manufacturing industries. However, after the global economic crisis in 2008, Korea has stepped into a stage of sluggish development, and it became crucial to find a way to have alternative innovation within an existing industry basis. In 2013, the new Korean government has implemented the concept of 'the creative economy' in national strategies to solve these problems by developing services and contents that focused on creative convergence industries. This system was built to cooperate and support various spectrums, and clarify vital relationships between the government, enterprises, and universities. Students with competence and experience obtained through the overall innovation processes of commercializing creative ideas are ideal for the creative workforce which enterprises are looking for, and this transition of system will provide opportunities to reinforce national competitiveness as a result. In this paper, we will propose a "Students Customized Creative Education Model" based on open innovation by reconstructing internal and external systems of universities and support projects to foster creative talents suitable for the creative economy. Subsequently, we will analyze the performance results and discuss the direction of future development.

\section{Research question}

How can we create a way to drive student involvement in the innovation process of commercializing creative ideas?

\section{Methods}

The scope, content, and method of this study were as follows: First, through literature review, the current situation was examined based on concepts and relations of the creative economy and open innovation, and the need for a convergence education curriculum based on interests between enterprises, government, and universities was also reviewed. Second, a case study was carried out in other universities under the operation system of a creative convergence education curriculum, and its execution, including contents, configurations, and operating conditions was analyzed. Based on this research, the government's support projects from inside and outside the university and the non-government enterprise supports such as competitions were redefined, and the innovation process capable of commercializing creative ideas was constructed into the creative educational model. This new concept model was configured to compensate for the needs and outcomes of students as the main benefiters of education. Third, the proposed model, the CHEESE program, was used for upperclassman designengineering students at Kumoh National Institute of Technology, South Korea between 2013 and 2015. The comprehensive earnings and results from the extended case studies were analyzed. Through the analysis of theoretical studies, case studies, and results from the established model, the direction of future development for the specialized creative education curriculum was proposed (Fig. 1). 


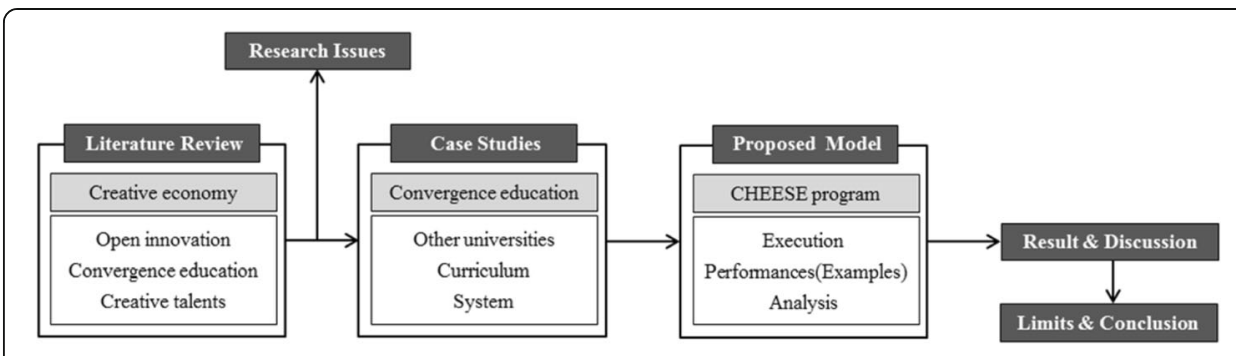

Fig. 1 Research framework

\section{Literature review}

Creative economy

The world economy is undergoing a crisis as it enters a serious low-growth era after the global financial crisis of 2007-08. The era-leading core growth-paradigm proposed new alternatives that focused on "value-oriented" in order to overcome these problems. Coy (2000) emphasized the emergence of a new economic system and defined the term "creative economy" to mean the economic structure where individual creativity, imagination, and ideas act as the key elements to generate social wealth. Lee (2013) suggested that as the knowledge-based society was established in South Korea, the support and preparation for the creative economy era that consist of integrated and creative industries as pivots, are the growth engines to lead the full-fledged knowledge and information age effectively. Particularly in Korea, the government since 2008 has engaged in various support policies for the "creative economy" in the direction of the national administration (Table 1).

\section{Open innovation}

The traditional closed innovation paradigm is no longer operating in the management and development of creative economy. Chesbrough (2003) mentioned that "In the closed innovation paradigm, they are screened and filtered during the research process. Although there were many ideas, few of them were available outside the walls of these firms. He added that in a changing era, there will be more opportunities of practicing with consumers, beyond listening to the voice of consumers or judging the ideas within the enterprise. Also, in this process, Chesbrough (2003) insisted that "the practice of learning (learning by doing)" is significant in open innovation.

In order to nurture the creative talents for a creative economic era, the universities should be aware the consumers are the students, who are the center of education. By

Table 1 Economic Paradigm of Republic of Korea (Lee 2013)

\begin{tabular}{llll}
\hline Classification & Industrial Economy & Knowledge Economy & Creative Economy \\
\hline Period & 70s-80s, Oil Crisis & 90 s, IMF Currency Crisis & Global Financial Crisis \\
Growth Paradigm & Industrialization & Informatization & Creation \\
Production Factors & Labor, Capital & Knowledge, Information & $\begin{array}{l}\text { Collective Intelligence } \\
\text { and Creativity }\end{array}$ \\
Core Industries & Heavy Chemical Industry & IT and Digital Industry & $\begin{array}{l}\text { Integrated and Creative } \\
\text { Industry }\end{array}$ \\
& & & $\begin{array}{l}\text { Smartphone, IT Convergence, } \\
\text { Success Story }\end{array}$ \\
& Shipbuilding, Steel Products, & $\begin{array}{l}\text { Semiconductors, Information } \\
\text { and Communications }\end{array}$ & \begin{tabular}{l} 
Korean-wave Contents \\
\hline
\end{tabular}
\end{tabular}


considering the students as consumers of education, it is essential to understand what is required at each step in the process for the students who want to realize their own creative ideas. Likewise, this context applies to the industry's efforts in responding to rapidly changing markets. Kodama and Shibata (2015) contended the importance of the consumer-centric approach by stating that "people don't know what they want until you show it to them. That's why I never rely on market research. Our task is to read things that are not yet on the page." Nho (2016) insisted that "Open innovation is regarded as a crucial methodology for the growth of organizations such as universities and public research institutes as well as companies. Open innovation explains why knowledge sharing and cooperative work between in and out- bound of organizations are important." The scope of R\&D consisting mainly of university professors with expertise is no longer research based, yet the concept is extending to the activities associated with business in the concept of R\&BD (Research \& Business Development). Increasingly, the university will be encouraged to transfer those ideas into innovative products, rather than basic research. Beyond the level of the scientific or foundational research conducted in the existing universities, the practical ideas which are appropriate for the market at the level of utilizing the foundation or companies' ideas will be needed in the short term. In order to actualize the learning environment through research and practice in the university, the role of the government and external companies are crucial. Chesbrough (2003) stated that "In many industries today, the logic supporting an internally oriented, centralized approach to R\&D has become obsolete. Useful knowledge is widespread in many industries, and ideas must be used with alacrity if they are not to be lost. These factors create the new logic of Open Innovation, which embraces external ideas and knowledge in conjunction with internal R\&D. This logic offers new ways to create value, along with the continuing need to claim a portion of that value." In basic open innovation, external ideas and knowledge in conjunction with internal $R \& D$ were created and formed into the new logic and new value.

\section{Fostering creative talents}

With the aim of human resource development for the creative economy era, universities have played an important role. In order to attain the creative economy, Lee (2013) created the countermeasures for each organization: companies, central government, local governments, university and research institutes, and the public. Above all, he argued that in universities, it is more important to strengthen the convergence program and groundwork of convergence human resource cultivation, as well as foundations. This means that the orientation and structure of university education have to be designed in accordance with the relevant formation of the balanced requirements and roles of universities, companies, and the government. In addition, Ortega and Bagnato (2015) remarked that the university should be the generator of knowledge and indicated that "a university should not serve merely as a site for training human resources and course administrators, but needs to be a shaper of behavior and skills for the development of innovation with a direct impact on society." For the students, it is important to perceive the feasibility of the idea through practice of innovation process and fill the gaps between research and development, which are caused by the different goals. Yun, Lee, et al. (2016) observed the markets/industry as "many subjects whom we meet in markets pay more attention to business models than anything else", and "the necessity 
of new business models for access to new markets and new business models created by the combination of technologies and markets is being intensified more than ever". These characteristics of markets support the purpose of fostering creative talents that student can penetrate a market more easily, especially whom with innovative/creative skills and potential ideas can be developed.

\section{The importance of creative convergence education}

Ito (2013), who works for the integrated education organization MIT Lab, asserted that "Creativity is difficult to achieve through the education based on existing manufacturing and mass production. It should be constructed that group and atmosphere to be creative, where interest and passion of students can be displayed." This is relevant to frequent attempts of operating university programs focused on Problem Based Learning (PBL), Wilkerson (1996). PBL, which started in McMaster University Medical School in Canada in 1960, believes that student-centered learning cultivates students' positive attitudes and confidence through a troubleshooting process where they face problems in a real context, which results in effective self-directed learning (Barrows 1996). Also, Yun, Yang, et al. (2016) mentioned "many pieces of knowledge that determine the amounts and qualities of individual humans' decision making and behaviors are of fundamental differences because of the variations among individuals, which are made through autonomous learning that surpasses humans' direct learning.". When students are able to utilize their knowledge and autonomous learning skills, students learn the way of finding the optimal solution by undergoing trials and errors, and by doing that individual students can reflect one's strong and weak points in terms of practices and time management. For students, as they are preparing to enter the society and industry field, the correlations between the industry and university are essential in terms of acquiring practical experiences and applying their knowledge at a working-level. But also for the industry and government, this method is beneficial in fostering talents to drive industrialization within a rapid globalization and technological evolution (Etzkowitz 1997). In summary, the three fields must be linked to form a virtuous circle structure to provide the dynamics of the creative economy. In order to foster students' creative talents, convergence education based on concept of open innovation (system supported by internal/external exchanges) should be achieved, which will eventually develop students' creativity. Creative economy becomes the background for active exchanges in each field (Fig. 2).

\section{Limitation of previous research on student education}

As studied above, previous research has focused on the effects of education itself rather than focusing on students who are consumers of education. Therefore, this study focused on autonomous activities and processes of students who are major consumers of education beyond the scope of pedagogical research. This is a result of planning and operating a program that reflects reality, which is a differentiated characteristic of this paper, and it is meaningful to establish a reality-oriented activity into academics.

\section{Case studies: creative convergence education program}

Domestic and international institutions systemically promote various policies by maintaining a system to lead and prepare for the flow of convergence, for example, between 


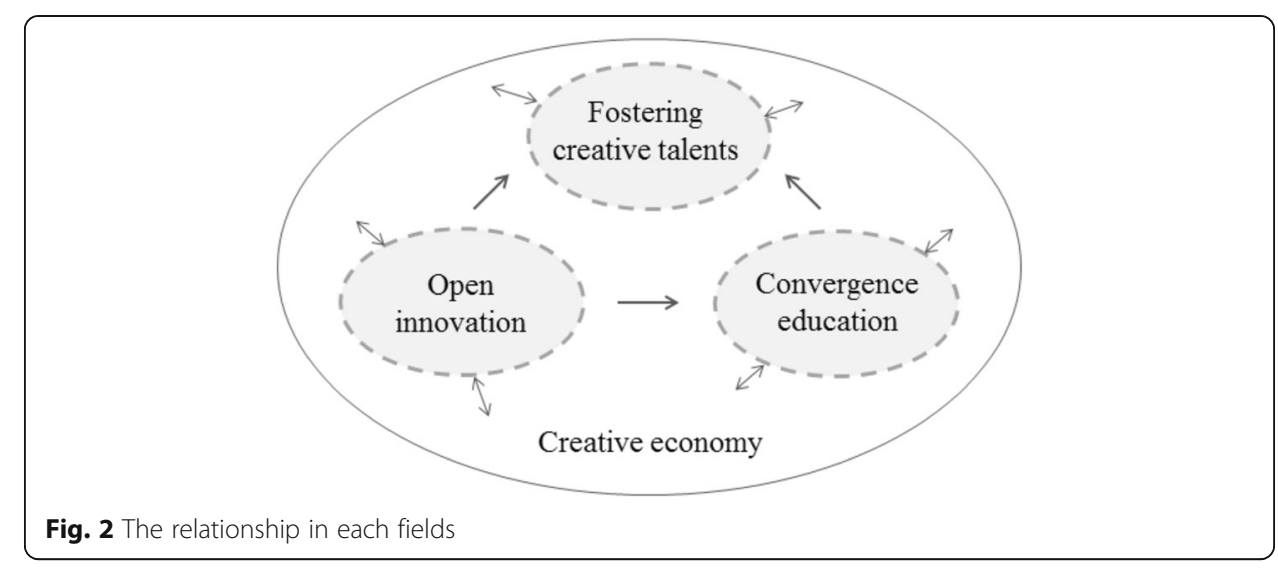

technology, liberal arts, and design, which is happening all across the industries. In particular, design is considered to be the core branch to lead the convergence flow of the creative economy and a number of plans are being prepared to utilize them in various fields. The design for advanced countries, from a convergence aspect, is an important factor that commercializes the idea and makes user-centric products. Therefore, realizing that design capabilities that support the infrastructure is essential, they are introducing policies to develop design skills (Europe 2020 flagship initiative innovation union, 2010). Thus, the convergence of university education is becoming more essential in order to support the activity of an institute that is based on a convergence policy, which is the essential way to prepare for the upcoming future. Recently, training creative convergence talent is a major issue in education, and to achieve this, design related convergence education is mainly being operated by Korea, which emphasizes the convergence of science, technology, and the arts. There are also a number of programs overseas being operated such as D-School in Stanford University and the Double Master's Joint Course, MA \&MSc from King's college London due to an early realization in the importance of creative convergence education, and has achieved effective results. In the case of Korea, Education courses operated by universities such as Seoul National University and UNIST gets supported Through National supported program called 'convergence design universities promotion business'.

As comparative research shows in Table 2, the curriculum of design-oriented creative convergence education at six domestic and foreign universities usually takes place in postgraduate studies based on major courses. Seoul National University in Korea has attempted to operate design-oriented creative convergence courses in their undergraduate program. This indicates that creative convergence education should be proactively executed in the early stage, and suggests the extended possibility of the curriculum to be established within undergraduate courses.

\section{Analyzing CHEESE program in open innovation}

The CHEESE Program is a volitional program that specializes in engineering manpower training for advanced undergraduate design-engineering students. This program started in 2013 and is still being run in 2016. The CHEESE program is based on the engineering and design amalgamated creative education process model, where experience and 
Table 2 Case study of creative convergence education program

\begin{tabular}{|c|c|c|c|c|}
\hline & $\begin{array}{l}\text { (Nation) University } \\
\text { and Major }\end{array}$ & Target and Semester & Major Configuration & Operation \\
\hline \multirow[t]{2}{*}{1} & $\begin{array}{l}\text { (USA) } \\
\text { Massachusetts } \\
\text { Institute of } \\
\text { Technology }\end{array}$ & \multirow{2}{*}{$\begin{array}{l}\text { (postgraduate course) } \\
\text { Master/PhD } \\
\text { * Students who have } \\
\text { completed master } \\
\text { degree in other } \\
\text { schools; their PhD } \\
\text { will be decided } \\
\text { according to the } \\
\text { result of Master } \\
\text { performance in } \\
\text { media lab }\end{array}$} & \multirow{2}{*}{$\begin{array}{l}\text { (Postgraduate course) } \\
\text { Compulsory to take } \\
\text { chemistry or physics as } \\
\text { major, focused on class } \\
\text { meeting and individual } \\
\text { oriented research, } \\
\text { possible to audit classes } \\
\text { such as Harvard, MIT, } \\
\text { MFA, Massart, Thesis } \\
\text { (PhD course) research } \\
\text { project }\end{array}$} & \multirow{2}{*}{$\begin{array}{l}\text { - Process: Imagine- > Create- } \\
\text { > Experiment > Reflect } \\
\text { - Engineering, Physics, } \\
\text { neuroscience, architecture, } \\
\text { design based convergence } \\
\text { education } \\
\text { - Academic system and } \\
\text { support from enterprise } \\
\text { - Venture related class } \\
\text { and start-up support }\end{array}$} \\
\hline & $\begin{array}{l}\text { Media Lab } \\
\text { (master of } \\
\text { science degree } \\
\text { in media arts } \\
\text { and sciences) }\end{array}$ & & & \\
\hline 2 & $\begin{array}{l}\text { (USA) } \\
\text { Stanford University }\end{array}$ & \multirow{2}{*}{$\begin{array}{l}\text { (Postgraduate course) } \\
\text { Master } \\
4 \text { times a year of open } \\
\text { admission system }\end{array}$} & \multirow{2}{*}{$\begin{array}{l}\text { - Comprehensive design } \\
\text { studio and creative } \\
\text { innovation based major } \\
\text { - Boot camp, pop-up } \\
\text { class, among others }\end{array}$} & \multirow{2}{*}{$\begin{array}{l}\text { - Design, engineering, } \\
\text { education, society, } \\
\text { management, biology, } \\
\text { industry based } \\
\text { convergence education } \\
\text { - Debate, performance } \\
\text { based class } \\
\text { - Design and industry- } \\
\text { university project }\end{array}$} \\
\hline & d. school & & & \\
\hline \multirow[t]{2}{*}{3} & $\begin{array}{l}\text { (UK) } \\
\text { Royal college } \\
\text { of art }\end{array}$ & \multirow{2}{*}{$\begin{array}{l}\text { Double Master's Joint } \\
\text { Course (two years), } \\
\text { MA (RCA) \& MSC } \\
\text { (Imperial College } \\
\text { London) }\end{array}$} & \multirow{2}{*}{$\begin{array}{l}\text { - Disruptive Market } \\
\text { Innovations } \\
\text { - Experimental Design } \\
\text {-Group \& Solo project } \\
\text { - Critical \& Historical Studies }\end{array}$} & \multirow{2}{*}{$\begin{array}{l}\text { - Postgraduate Student } \\
\text { Loan of up to } £ 10,000 \\
\text { per course - workshop, } \\
\text { seminar, student teaching } \\
\text { workshop industry- } \\
\text { university project } \\
\text { - Prototype production } \\
\text { support }\end{array}$} \\
\hline & $\begin{array}{l}\text { Innovation Design } \\
\text { Engineering, IDE }\end{array}$ & & & \\
\hline \multirow[t]{2}{*}{4} & $\begin{array}{l}\text { (Germany) } \\
\text { Technische } \\
\text { Universität } \\
\text { München }\end{array}$ & \multirow{2}{*}{$\begin{array}{l}\text { (Postgraduate course) } \\
\text { industrial design } \\
\text { curriculum has been } \\
\text { provided to variety of } \\
\text { majors such as } \\
\text { architecture, machinery, } \\
\text { information, business } \\
\text { engineering Administration }\end{array}$} & \multirow{2}{*}{$\begin{array}{l}\text { - Design theory \& } \\
\text { multidisciplinary } \\
\text { related field } \\
\text { - Project: Design-utilized } \\
\text { product, service and } \\
\text { brand development } \\
\text { - Personal research } \\
\text { and thesis at } \\
\text { systemic level }\end{array}$} & \multirow{2}{*}{$\begin{array}{l}\text { - Modular education } \\
\text { (Diploma course students } \\
\text { \& Master course students } \\
\text { participated) } \\
\text { - Utilize methodology } \\
\text { such as theory, seminar, } \\
\text { research } \\
\text { - Focused on company } \\
\text { experience and } \\
\text { understanding through } \\
\text { project and internship }\end{array}$} \\
\hline & $\begin{array}{l}\text { Master of } \\
\text { Industrial Design }\end{array}$ & & & \\
\hline \multirow[t]{2}{*}{5} & $\begin{array}{l}\text { (South Korea) } \\
\text { Seoul National } \\
\text { University }\end{array}$ & \multirow{2}{*}{$\begin{array}{l}\text { (Undergraduate) } \\
40 \text { students a year, } \\
\text { More than } 3 \text { semesters } \\
\text { registered to students } \\
\text { who are assigned to } \\
\text { selected undergraduate } \\
\text { major, obtaining certain } \\
\text { grade }\end{array}$} & \multirow{2}{*}{$\begin{array}{l}\text { - Compulsory program } \\
\text { of integrated creative } \\
\text { design (selected } \\
\text { undergraduate: } \\
\text { recommend students } \\
\text { who are assigned to } \\
\text { Design, Management, } \\
\text { Mechanical and } \\
\text { Aerospace Engineering, } \\
\text { Industrial Computer } \\
\text { Engineering, Architecture, } \\
\text { Electrical Engineering, } \\
\text { Consumer Pedology, } \\
\text { Psychology, Clothing } \\
\text { department chooses } \\
\text { interdisciplinary program) }\end{array}$} & \multirow{2}{*}{$\begin{array}{l}\text { - Government expenditure } \\
\text { supported program which } \\
\text { has been established } \\
\text { in } 2009 \\
\text { - Team teaching and team } \\
\text { work focused education } \\
\text { - Supports foreign internship } \\
\text { and training by creating } \\
\text { industrial oriented } \\
\text { education environment. } \\
\text { - Opportunity to attend } \\
\text { workshop, group activity } \\
\text { seminar, conference, } \\
\text { exhibition and entry } \\
\text { fee supported }\end{array}$} \\
\hline & $\begin{array}{l}\text { Integrated Creative } \\
\text { Design } \\
\text { Interdisciplinary } \\
\text { program }\end{array}$ & & & \\
\hline \multirow[t]{2}{*}{6} & $\begin{array}{l}\text { (South Korea) } \\
\text { UNIST }\end{array}$ & \multirow[t]{2}{*}{ (Postgraduate) } & \multirow{2}{*}{$\begin{array}{l}\text { - } 4 \text { Phase project-based } \\
\text { integrated Univ-Industry } \\
\text { Cooperation courses } \\
\text { - Design \& Engineering } \\
\text { Integrated Project, } \\
\text { Master Graduation } \\
\text { Project }\end{array}$} & \multirow{2}{*}{$\begin{array}{l}\text { - Creativity/convergence/ } \\
\text { globalization } \\
\text { - Research facility } \\
\text { - Project to exchange } \\
\text { actively with foreign } \\
\text { universities } \\
\text { - Supports industry } \\
\text { internship and start-up } \\
\text { training }\end{array}$} \\
\hline & $\begin{array}{l}\text { Postgraduate } \\
\text { School of Design } \\
\text { Convergence } \\
\text { specialty }\end{array}$ & & & \\
\hline
\end{tabular}


the learning of integrated creativity are linked with patents, open exhibition, and commercialization with results that were gained through the design engineering convergence process from research, idea, design, prototyping, and evaluation. This open innovation concept based model has a goal of providing an entrepreneurial spirit and giving students an opportunity to try commercialization by having students to share their ideas and link them with internal and external supports. This program has realigned the student-centered process and related systems to utilize various systems, which have been supported from the university's internal and external support as part of training the creative manpower to have an entrepreneurial spirit, which is suitable for the creative economy era. Furthermore, this program was created to supply material and environmental support, short-term outcomes and rewards, and various experiences that consider the students' specialty and circumstances (Table 3).

On the left hand side of Fig. 3, we can see the previous situation before the CHEESE program was executed, where each project was operated independently and the students received support from enterprises of different purposes such as manpower training, industry-university cooperation, and authentication business. We defined this as a closed innovation system. Since this system was not systemically linked between the supporting systems in one flow, temporary performance was derived as an outcome, yet it was difficult to consolidate the outcomes efficiently and effectively. In contrast, in an open innovation system, which is used in the CHEESE program, the relocated configuration based on existing support projects focuses on student-centered activities with consistency and persistency, where the quality and educational effectiveness of outcomes can be improved. For the students, it is important to perceive the feasibility of the idea at every step of practice throughout the entire innovation process to fill the gaps between research and development that are caused by the different goals (Fig. 4).

According to Oganisjana (2015), 11 necessary requisites (experience, knowledge, advice, problem solving, new ideas, other view of life, creativity, inspiration \& motivation, critical thinking, creation, support, intergenerational awareness, new opportunities) for convergence exchange inside of the university (entrepreneurs, students, university education) have been extracted from the students' position and, apparently, these requisites are worthwhile for an open innovation environment and intergenerational collaboration. As indicated in the diagram below, these requisites can be reclassified to the necessary requisites for the CHEESE program. These requisites also

Table 3 Definition of CHEESE program in Open innovation

\begin{tabular}{ll}
\hline Concept in Open innovation & - Open innovation-based CHEESE program has a goal of development \\
& design in product, service, and system through ideation, visualization, \\
& prototype manufacturing, evaluation, and commercialization. \\
Features in Open innovation & - Process that aims for design and technology convergence. \\
& - Progress based on process participants' curiosity, open mind, \\
& and volition. \\
- Learn some necessary requisites for capability, such as attitude, \\
skills, and knowledge \\
- Internal/External supporting in open innovation \\
- Includes applying for patent/intellectual property rights and \\
registration process in early stage of process. \\
- Considers commercialization with practical results such as awards \\
and applying for patents and foundation. \\
- Short-term compensation in connection with internal and external \\
support programs for results at each stage
\end{tabular}




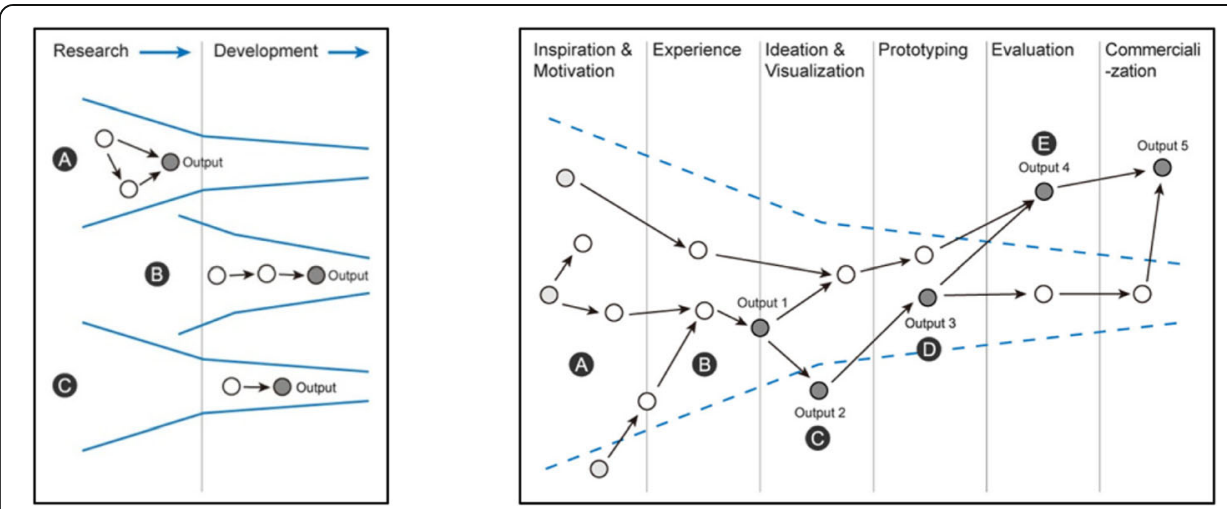

Fig. 3 Closed innovation system vs. open innovation system

share the same context of students' needs and valuable elements that the program tries to offer (Table 4).

Internally, typical projects supported inside the university include the ACE and LINK projects, which is Advancement of College Education and Leaders in IndustryUniversity Cooperation. ACE is a government supported project that is trying to create "good teaching universities". The project selects universities that have distinct features and competitiveness in order to create an outstanding model, which is diverse and pacesetting in undergraduate education, which realizes an ideology in establishing the university's vision and ideal "man of ability". The project also supports the development and management of the universities' voluntary educational process so that the education support system can be improved in general. In addition, ACE creates an educational program and system to meet the demand of an industrial society, as it reinforces undergraduate students' employability and foundation ability by aiming to train

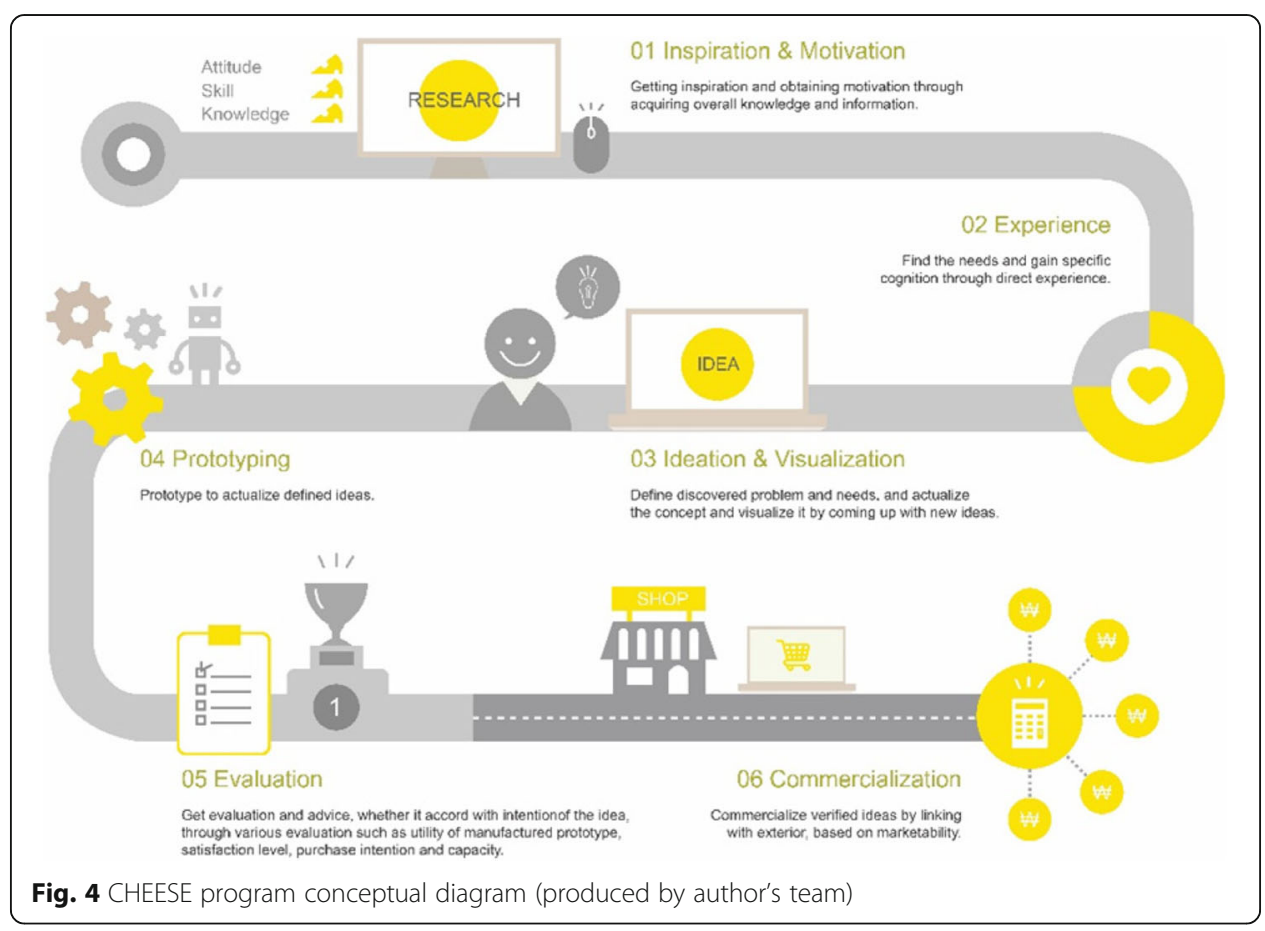


Table 4 Activities and necessary requisites for each step of CHEESE program

\begin{tabular}{|c|c|c|c|}
\hline & $\begin{array}{l}\text { Steps of CHEESE } \\
\text { Program }\end{array}$ & Activities & $\begin{array}{l}\text { Necessary requisites for } \\
\text { convergence exchange } \\
\text { based on Oganisjana (2015) }\end{array}$ \\
\hline 1 & Inspiration \& Motivation & $\begin{array}{l}\text { Getting inspiration and obtaining motivation } \\
\text { through acquiring overall knowledge and } \\
\text { information. } \\
\text { (Research of life style, trends, users, technology) }\end{array}$ & $\begin{array}{l}\text { Knowledge, other views on } \\
\text { life, inspiration \& motivation }\end{array}$ \\
\hline 2 & Experience & $\begin{array}{l}\text { Find the needs and gain specific cognition } \\
\text { through direct experience. } \\
\text { (Field trip, town watching, seminars, workshops) }\end{array}$ & $\begin{array}{l}\text { Experience, } \\
\text { intergenerational awareness }\end{array}$ \\
\hline 3 & Ideation \& Visualization & $\begin{array}{l}\text { Define discovered problem and needs, and } \\
\text { actualize the concept and visualize it by } \\
\text { coming up with new ideas. } \\
\text { (Sketching, modeling, rendering, presentations) }\end{array}$ & $\begin{array}{l}\text { Problem solving, new ideas, } \\
\text { creativity }\end{array}$ \\
\hline 4 & Prototyping & $\begin{array}{l}\text { Prototype to actualize defined ideas } \\
\text { (3D Printing, mock-up, simulation) }\end{array}$ & Creation \\
\hline 5 & Evaluation & $\begin{array}{l}\text { Get evaluation and advice, whether it agrees } \\
\text { with the intention of the idea, through various } \\
\text { evaluations such as utility of manufactured } \\
\text { prototype, satisfaction level, purchase intention, } \\
\text { and capacity. } \\
\text { (Test of usability/emotion/satisfaction, exhibition) }\end{array}$ & $\begin{array}{l}\text { Advice, critical thinking, } \\
\text { support }\end{array}$ \\
\hline 6 & Commercialization & $\begin{array}{l}\text { Commercialize verified ideas by linking with } \\
\text { externals based on marketability } \\
\text { (Technology licensing, business linkage, foundation) }\end{array}$ & New opportunities \\
\hline
\end{tabular}

manpower in order to support the country's competitiveness through advancing undergraduate education for tech+ manpower cultivation (Table 5).

The LINC project pursues the realization of a creative economy ecosystem, which enables universities and companies to grow together. It aims to create and diffuse various industrial cooperation leading models through supporting the industrial cooperation family company, achieving a $60 \%$ employment rate of local universities, and choosing industrial cooperation leading universities. For this, the model reinforces the support of breaking away from the engineering universities' center of industrial cooperation and foundation, and supports the creation of various leading models by giving modularized and dimensionalized support through local industry-based characterization. In addition, the LINC project enhances the possibility of maintaining industrial cooperation and reinforcing the role of industrial cooperation through restructuring the industrial cooperation-friendly system and phased business management. In other words, the project wants to create a business where companies put the universities' technology and human resources to use, and where universities reinforce the education and research capability that satisfy the industrial setting demand and forming characterization. These support projects were created to support students in gaining capability by linking internal and external activities. These projects include environmental support such as studios, idea competitive exhibition entry support, and prototype manufacturing support (Table 5).

Externally, there is a project supported by the Korean government for business and foundations related to creative manpower cultivation and creative economy vitalization. It consists of an integrated support system that links mentor connection, exhibition, prototype manufacturing support, and route to market in each step to the idea of commercialization from supporting an active environment such as studios. In addition, 


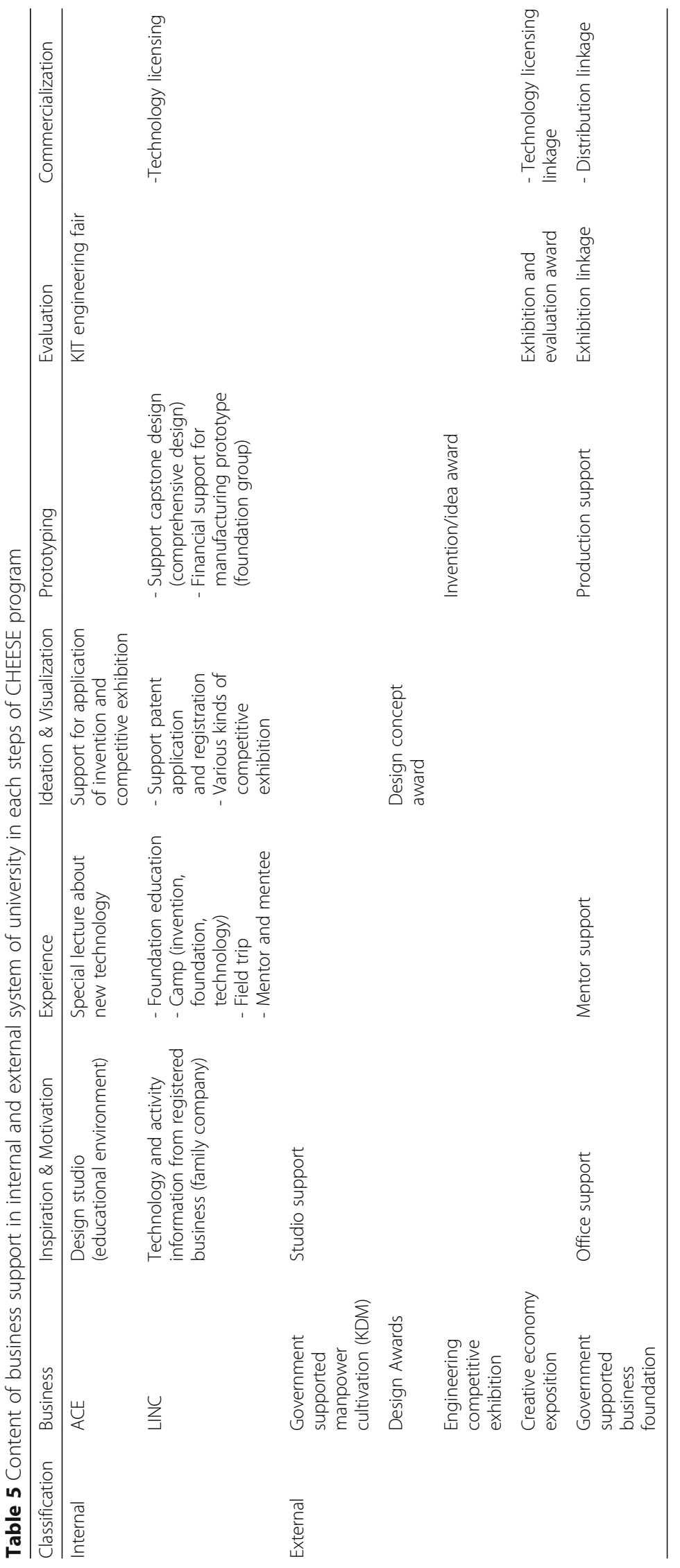


there are various design awards and competitions for acknowledging differentiation and the standard of idea and possibility of realization. This project helps students to get to know the marketability. Occasionally, external companies affiliate themselves with commercialization when good ideas are discovered through those announcements and exhibitions. In terms of humans and material, the external support has larger expandability than university support systems. The external support is effective when university supported ideas are actualized. In the next section, we will examine what kind of activity and supports have been taken to perform the entire process through the following 2 cases, which were real outcomes of the proposed "CHEESE program" (Table 5).

\section{Case 1: student A}

Outline

- Product name: Cleanse (Clens)

- Product description: "Clens" is a new concept of a disposable contact lens case that solves sanitation problems, including bacterial infections caused by unavoidable external touch such as lens tweezers and fingers. Clens is an item that uses the structure of small cymbals. When users push the bottom side to upwards, the feature stretches while embracing the finger, which enables users to wear the lens without the need for lens tweezers or touching the lens with fingers. As a result, users feel less bothered because there is no external touch and concerns of bacterial infection decreases. This product is ideal for those who highly regard sanitation and eyeball health.

- Project period: 2014.3.3 2015.05.18

- Major Performances: K-design Award prize; Reddot Winner award; creative intellectual property [design] commercialization support in 2014; acquired 4 design patents; submitted to Creative Economy Expo 2015; signed contract on linkage commercialization (Innovartis and MOU) (Fig. 5).

\section{Phased activity Caused by Proposed Model (CHEESE program)}

Student A developed this idea from a club activity to solve the inconvenience she felt in her daily life. She actualized and developed the idea by utilizing the "CHEESE program"

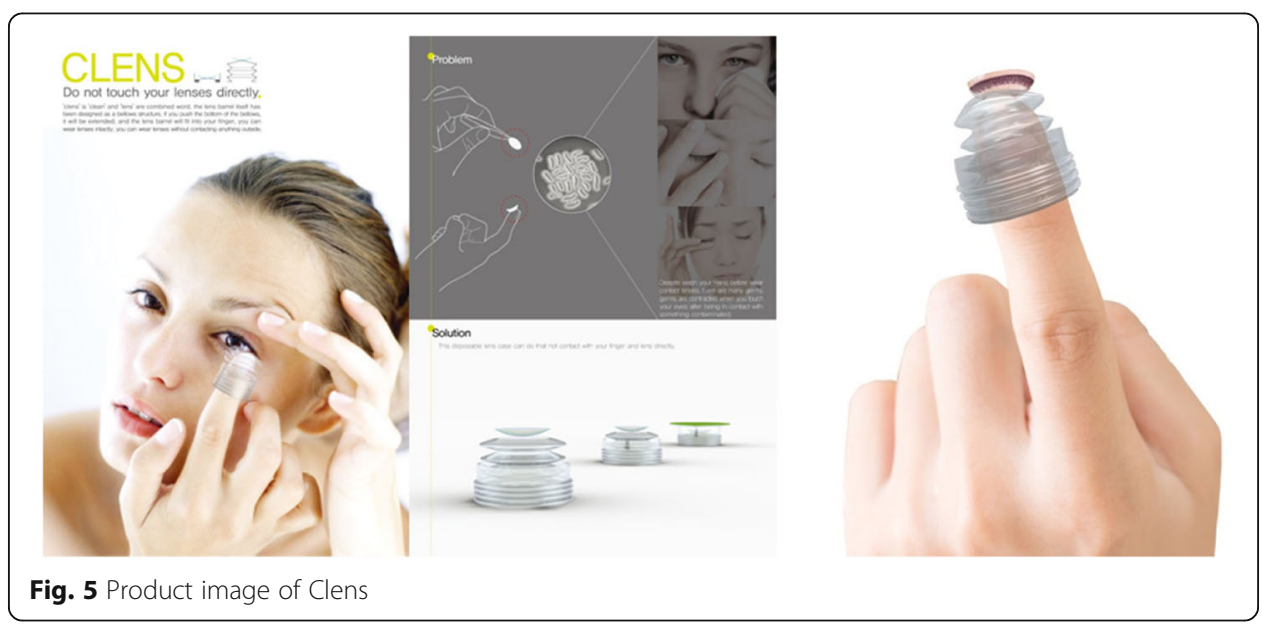


step-by-step and having a support system. The ideas realized in each step became a resource and basis for the project to be developed. A long and difficult process of developing new products could have been experienced due to the short-term outcome such as patent applications, awards, and exhibitions, and continuous stimulation with rewards was gained in every step.

\section{(1) Inspiration \& Motivation}

The (internal) study of making ideas was done in the "laboratory resident" activity, which was supported by the ACE project. The laboratory activities created an environment for coming up with ideas, so participants were able to discuss the direction of the product's development. Through a regularly conducted idea verification time, the item for "hygienic lens container" was discovered (Table 6).

(2) Experience (Internal open innovation) discovering problems by progressing research about development items and defining was processed through the "Start-up Club" activity, which was supported by the LINC project. Indirect experience in product development was obtained by gaining support to attend idea expositions, various exhibitions, or do market research (Table 6).

(3) Ideation \& Visualization When an organized idea concept comes out, it is visualized to features such as modeling and rendering. The concept becomes ready to be applied to a claim and presented to others (Table 6).

(Internal open innovation) Attending global events can happen through the support of the LINK project in patent and intellectual property applications about idea (a) and international travel expenses for (b) design award attendance fees and awards. This linking between external and internal support systems helps makes students' ideas become more valuable (Table 6).

(External open innovation) The German "Reddot" Design Award, which is one of the world's three major design awards, is an opportunity to make ideas be verified at a world-wide level (only 5.1\% of a total of 4761 attendants from 60 countries are selected as winners) and the ideas were submitted through the support of the university, and selected as a winner (2014.9.6) (Table 6).

(4) Prototyping

The prototype becomes supported by being selected as a creative idea that is most likely to be commercialized. This process occurs by having the students apply for the "Creative

Table 6 Open innovation activities in CHEESE program

\begin{tabular}{|c|c|c|c|c|c|c|c|}
\hline Classification & & $\begin{array}{l}\text { Inspiration \& } \\
\text { Motivation }\end{array}$ & Experience & $\begin{array}{l}\text { Ideation \& } \\
\text { Visualization }\end{array}$ & Prototyping & Evaluation & Commercialization \\
\hline \multirow{2}{*}{$\begin{array}{l}\text { Internal open } \\
\text { innovation }\end{array}$} & $\mathrm{ACE}$ & $\bullet$ & & & & & \\
\hline & LINC & & $\bullet$ & $\bullet$ & & & \\
\hline \multirow[t]{3}{*}{$\begin{array}{l}\text { External open } \\
\text { innovation }\end{array}$} & $\begin{array}{l}\text { Design } \\
\text { Awards }\end{array}$ & & & $\bullet$ & & & \\
\hline & $\begin{array}{l}\text { Creative } \\
\mathbb{I}\end{array}$ & & & & $\bullet$ & & \\
\hline & Exposition & & & & & $\bullet$ & $\bullet$ \\
\hline
\end{tabular}


Intellectual Property [Design] Commercialization Support Program (2014)", which is supported by the Small Business Administration and patent office.

Prototyping is a stage where the idea is actualized from the concept, and production costs are directly invested into it. This makes this step important for students to go through (Table 6).

(5) Evaluation

(External open innovation) Students had an opportunity to verify the possibility of idea commercialization through market research and evaluation by exhibiting in a creative economy exposition in 2015 at Seoul Coex, which was held by the support of several Korean government institutions and organizations, where creative economic activities mainly occur. By targeting people who participate in the exposition, the product's acceptance and attraction, results after evaluating the required improvements, design suitability, functional interest, and facilities of use were evaluated intensely. Participating in this exposition became an opportunity to examine the future progress of "commercialization", as the purchase intention and marketability was shown to be above average (Table 6).

(6) Commercialization

(External open innovation) The German company "Innovartis", a leading idea commercialization specialist, visited the creative economy exposition in 2015. They signed an MOU as they considered the product "Clens" highly. In addition, they promised to cooperate and help serve actively commercialization enterprises or with the technology licensing that may occur in the future (Table 6).

\section{Case 2: student B}

Outline

- Product name: The changing face tissue case

- Product description: This cute shape tissue case not only acts as a case, but is also aware whenever the tissue pops up by utilizing Arduino and PIR sensors (Passive Infrared Sensor). The shape of the tissue case's eyes, which was designed with LED, changes according to the frequency of tissues popping up. This case intends to make users pay attention to the environment by inducing users to economize tissues.

- Progress period: 2014.9 2015.5

- Major Performances: Recipient of Gumi University's Eighth Invention and Founding Idea Competition Award (Creative Korea) and the World's Woman Invention Competition Award (KIWIE); acquired design patent; made a contract with GDP Design Company and MOU, as well as technology licensing (Fig. 6).

\section{Phased activity caused by proposed model (CHEESE Program)}

Student B also developed and actualized the idea by utilizing the step-by-step activity of the "CHEESE program" and support system. In this case, the prototyping stage was supposed to be the main consideration, but the product was a developed working mock-up that considers both hardware and software through the design and technology convergence educational program. This experience shows that by going through the process of making an actual real activation and improving it in creative education, the 


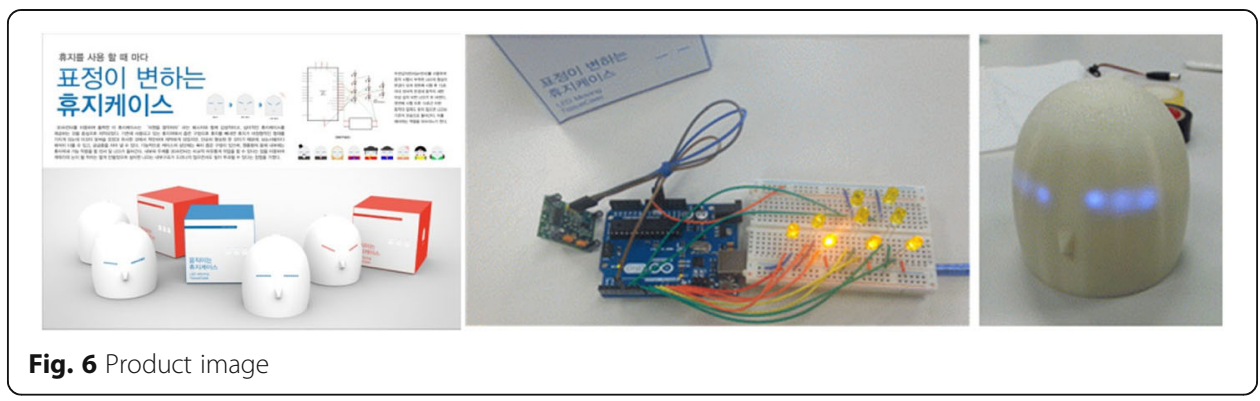

commercialization of ideas is very important. The students experience a practical way of adding more value into creative ideas by utilizing technological ideas that only exist in imagination. In this case, short-term achievement was also gained in every stage (patents, awards, exhibitions), and outcomes were achieved by following technology licensing for commercialization.

(1) Inspiration \& Motivation

(External) The students get stimulus and are inspired by continuously discovering ideas through various seminars and exhibitions that are was held by district design promotion institutions DGDC (Daegu Gyeong-Buk Design Center). The students also do idea excavating and project activities by acting as a KDM member (Korea Design Membership: system which selects design-related students who have competitiveness), which links school activities with international activities (Table 7).

(2) Experience (Internal) Many students worked together as a team through the "Start-up club" activity, which was supported by the LINK project. The students worked together on a theme of idea excavating utilizing 3D printing. One of the individual ideas, the tissue case, was selected, which was then quickly prototyped. The idea was actualized through numerous 3D printing experiments. This process became an opportunity and experience to verify ideas freely through utilizing 3D printing support, not just in the laboratory, but also in the university (Table 7).

(3) Ideation \& Visualization (Internal) Design rights were applied through patent and intellectual property applications. This was supported by the LINK project. (2015/2/5) (Table 7).

(4) Prototyping

Table 7 Open innovation activities in CHEESE program

\begin{tabular}{|c|c|c|c|c|c|c|c|}
\hline \multicolumn{2}{|l|}{ Classification } & \multirow{2}{*}{$\begin{array}{l}\text { Inspiration \& } \\
\text { Motivation }\end{array}$} & \multirow[t]{2}{*}{ Experience } & \multirow{2}{*}{$\begin{array}{l}\text { Ideation \& } \\
\text { Visualization }\end{array}$} & \multirow[t]{2}{*}{ Prototyping } & \multirow[t]{2}{*}{ Evaluation } & \multirow[t]{2}{*}{ Commercialization } \\
\hline Internal & ACE & & & & & & \\
\hline $\begin{array}{l}\text { open } \\
\text { innovation }\end{array}$ & LINC & & $\bullet$ & $\bullet$ & $\bullet$ & $\bullet$ & $\bullet$ \\
\hline \multirow{3}{*}{$\begin{array}{l}\text { External } \\
\text { open } \\
\text { innovation }\end{array}$} & $\begin{array}{l}\text { Design } \\
\text { Awards }\end{array}$ & $\bullet$ & & & & & \\
\hline & $\begin{array}{l}\text { Creative } \\
\text { Korea }\end{array}$ & & & & & $\bullet$ & \\
\hline & KIWIE & & & & & $\bullet$ & \\
\hline
\end{tabular}


(Internal) prototype production was supported by the Foundation Club activity, which was supported by the LINK project. Flaws were reformed after a number of test productions for continuous operations from the idea stage (Table 7).

(5) Evaluation

(Internal open innovation) In the university, the KIT Engineering Fair is held once a year. The KIT Engineering Fair is an exhibition which enables students to present their research outcomes. Through this exhibition, the companies and individuals have an opportunity such as cooperating together and presenting awards to projects that had outstanding results. The participants also can look at valuable ideas or technology. The developed tissue case was selected as an outstanding product and was selected for a competitive exhibition. In addition, the expenses associated with applying for the competitive exhibition was supported through the ACE project (Table 7).

(External open innovation) The project obtained a participation award from Creative Korea in 2014, and a Silver Award and Dongguk University Chancellor Award from 'KIWIE (Korea International Women's Invention Exposition) in 2015, which was sponsored by the Korean Invention Institute (Table 7).

(6) Commercialization

(Internal/External) A stake contract was completed with the GDP Design Company, which is a family company that made an agreement with Kumoh National Institute of Technology through the KIT Engineering Fair in 2015. A technology licensing fee was given after technology licensing in order to commercialize the product in 2015. The project was also paid according to the idea's share ratio (Table 7).

\section{Results and discussion: academic contribution \& implication}

The suggested CHEESE program model was conducted, targeting upper level undergraduate students who are studying in industrial engineering design from 2013 to 2015. Every year, the activity result has obtained better outcomes, as it is shown in the graph below (Fig. 7). This means that the program, which was systematically built for supporting the activity in each step for developing one's own ideas, helped students to become stimulated for creative activities. In particular, the increased number in competition is highly significant in terms of preparing the opportunity, as students refine their ideas and receive objective verification on their ideas through external showcases. When a new program based on open innovation has applied, it was confirmed that students' creative talents and their ability in actualizing their ideas have improved. This is an academic contribution of open Innovation as a new model of educational program.

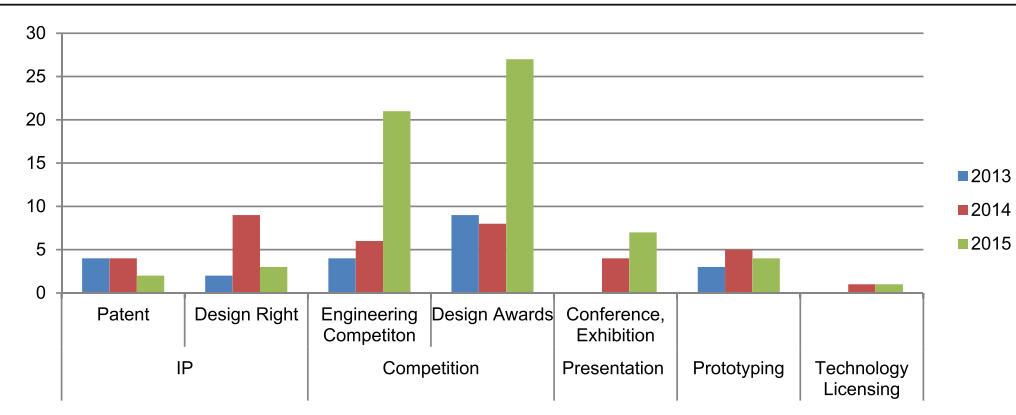

Fig. 7 Trend of results of student customized creative education model from 2013 to 2015 
The graph was created in order to observe each category. It shows that a total of 31 patents were applied in 3 years (10 cases of patents and 14 cases of design rights were registered). This created a $77.42 \%$ productivity achievement ratio of application contrast. The number of ideas that was applied to competition was 165 with 75 cases among them awarded. This forms a success rate of $45.45 \%$, an industrial competitive exhibition rate of $72.09 \%$, and a design award rate of $36.07 \%$. In the case of design awards, 5 cases among the 44 cases were international awards, which achieved in drawing global level ideas in the short-term. In addition, the engineering based industrial design convergence program performance result showed outstanding performance in engineering competitive exhibitions. This shows that it is more effective when design thinking or technology is used in projects. The projects that were supported for making prototypes were able to bring linking results such as presenting in exhibitions and conferences or awards in competitive exhibitions and technology licensing. Unlike the existing convergence program, which consists of a postgraduate course, it is shown that there is a possibility of continuous development in the proposed model, in terms of having a self-regulation undergraduate program. However, even though there were numerous challenges in the extent of arranging idea concepts, considering the characteristics of a creative educational model in undergraduate studies, it has been proven that there is a limitation in the actual business associated activities such as foundation or commercialization. There is an obvious difference from the result of standardizing differentiated ideas to making products that consider the actual development and marketability. It is shown that there is need for designing an advanced program to support it. If an improved model is developed that links undergraduate programs and postgraduate programs, good results could be obtained (Table 8).

In summary, the three related fields through the proposed model are interconnected to form a virtuous cycle structure. Open Innovation, in which the demand for industry and students is composed of internal/external systems, is embodied as a customized education program. Eventually, students who experience these programs improve their adaptability to the industry. It becomes the basis for building relations between industry, government, and schools (Fig. 8).

Table 8 Performances of CHEESE program in 3 years

\begin{tabular}{|c|c|c|c|c|c|c|}
\hline & & & 2013 & 2014 & 2015 & Total \\
\hline \multirow[t]{4}{*}{ Patent } & \multirow[t]{2}{*}{ Patent } & Application & 5 & 7 & 2 & 14 \\
\hline & & Registration & 4 & 4 & 2 & 10 \\
\hline & \multirow[t]{2}{*}{ Design right } & Application & 2 & 9 & 6 & 17 \\
\hline & & Registration & 2 & 9 & 3 & 14 \\
\hline \multirow[t]{4}{*}{ Competition } & \multirow{2}{*}{$\begin{array}{l}\text { Engineering } \\
\text { Competition }\end{array}$} & Application & 7 & 8 & 28 & 43 \\
\hline & & Awards & 4 & 6 & 21 & 31 \\
\hline & \multirow[t]{2}{*}{ Design Awards } & Application & 12 & 19 & 91 & 122 \\
\hline & & Awards & 9 & 8 & 27 & 44 \\
\hline \multirow[t]{2}{*}{ Presentation } & Exposition & & - & 3 & - & 3 \\
\hline & Conference & & - & 1 & 7 & 8 \\
\hline \multicolumn{3}{|l|}{ Prototyping } & 3 & 3 & 4 & 12 \\
\hline \multicolumn{3}{|c|}{ Technology Licensing } & - & 1 (MOU) & 1 (Contract) & 2 \\
\hline
\end{tabular}




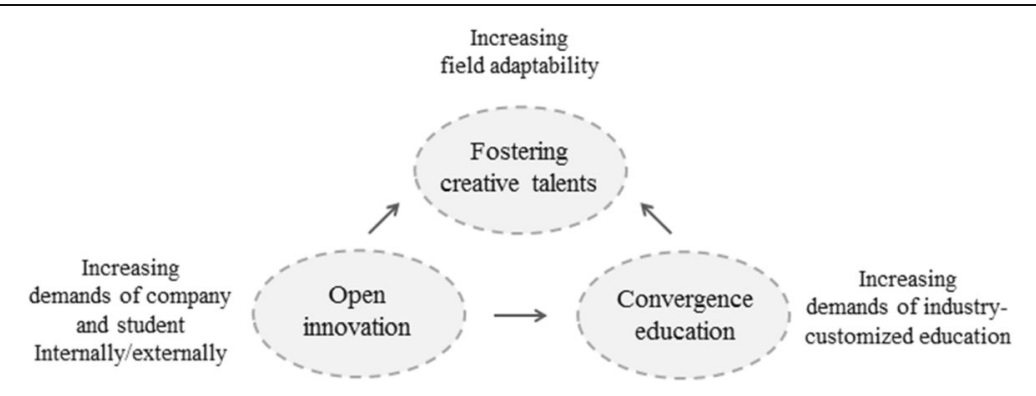

Fig. 8 Eco-system of three fields

\section{Limit \& conclusion}

This study had a test operation after the CHEESE program was designed. There are limits to generalization and standardization due to insufficient cases as it is conducted for specific volunteered students. Also it has not been able to apply the needs of industry in depth as it is made in the undergraduate course.

The CHEESE program is a creative convergence education based on open innovation where new systems and management methods are prepared to cultivate talented people that are needed in a creative economy era. The functions of the proposed concept, "Student Customized Creative Education Model", are as follows:

1. Conceptualization of creative education model that cultivates creative people to improve their intellectual added value and recreate knowledge needed in a creative economy (intellectual based) era.

2. This model will cultivate convergence ability, which gives solutions based on overall knowledge that considers the market, technology, and users in a balanced way, in order to solve complicated problems that occur in the field.

3. The model will allow students to obtain experience and encourage confidence through a series of practice processes that plan, design, produce, and evaluate in a self-directed way based on acquired knowledge.

4. The model will encourage leadership that constructs opportunities while linking the internal and external parts of university supporting projects, as well as effective and efficient communication and management of team work in each stage.

For students, the most meaningful aspect of this proposed model is actualizing and developing their own ideas, as well as being able to realize the professional process that is more than just the level of thinking ideas. In addition, the project helps students overcome various challenges and provides other opportunities by having students obtain long-term outcomes, while receiving short-term stimulus, encouragement, and rewards from the overall supporting system.

\section{Acknowledgement}

This research was supported by the MSIP(Ministry of Science, ICT and Future Planning), Korea, under the ITRC (Information Technology Research Center) support program(IITP-2016-H8601-16-1011) supervised by the IITP (Institute for Information \& communications Technology Promotion). 
Competing interests

The authors declare that they have no competing interests.

\section{Author details}

'Kumoh National Institute of Technology, Republic of Korea, \#543, Global Building, 61 Daehak-ro, Gumi, Gyeong-Buk, South Korea730-701. ${ }^{2}$ Kumoh National Institute of Technology, Republic of Korea, \#544, Global Building, 61 Daehak-ro, Gumi, Gyeong-Buk 730-701, South Korea. ${ }^{3}$ Kumoh National Institute of Technology, Republic of Korea, Gumi, South Korea.

Received: 20 July 2016 Accepted: 27 December 2016

Published online: 03 March 2017

\section{References}

Barrows, H. S. (1996). Problem-based learning in medicine and beyond: a brief overview. New Directions for Teaching and Learning, 1996(68), 3-12. do: 10.1002/tl.37219966804.

Chesbrough, H. W. (2003). Open innovation: the new imperative for creating and profiting from technology. Boston: Harvard Business School Press.

Coy, P. (2000). The Creative Economy. Business Week.

Etzkowitz, H. (1997). From zero-sum to value-added strategies: the emergence of knowledge-based industrial policy in the states of the United States. Policy Studies Journal, 25(3), 412-424. doi:10.1111/j.1541-0072.1997.tb00031.X.

Europe 2020 flagship initiative innovation union. (2010). Luxembourg.

Howkins, J. (2002). The creative economy: how people make money from ideas. London: Penguin Global.

Ito, J. (2013). Go beyond boundaries and disciplines. Tech \& Beyond

Kodama, F., \& Shibata, T. (2015). Demand articulation in the open-innovation paradigm. Journal of Open Innovation: Technology, Market, and Complexity, 1(1), 5-6. doi:10.1186/s40852-015-0003-y.

Lee, J. W. (2013). Understanding and countermeasures of the creative economy. Institute of Creative Economy.

Nho, H.-J. (2016). Research ethics education in Korea for overcoming culture and value system differences. Journal of Open Innovation: Technology, Market, and Complexity, 2(1), 3-4. doi:10.1186/s40852-016-0030-3.

Oganisjana, K. (2015). Promotion of university students' collaborative skills in open innovation environment. Journal of Open Innovation: Technology, Market, and Complexity, 1(1). doi:10.1186/s40852-015-0021-9.

Ortega, L. M., \& Bagnato, V. S. (2015). The practice of innovation at brazilian public university: The case of the university of São Paulo. Brazilian Journal of Science and Technology, 2(1), doi:10.1186/s40552-015-0011-2

Wilkerson, L. (1996). Bringing problem-based learning to higher education: theory and practice. United States: Jossey-Bass Inc., US.

Yun, J., Lee, D., Ahn, H., Park, K., \& Yigitcanlar, T. (2016). Not deep learning but autonomous learning of open innovation for sustainable artificial intelligence. Sustainability, 8(8), 797. doi:10.3390/su8080797.

Yun, J. J., Yang, J., \& Park, K. (2016). Open innovation to business model: new perspective to connect between technology and market. Science Technology \& Society, 21(3), 324-348. doi:10.1177/0971721816661784.

\section{Submit your manuscript to a SpringerOpen ${ }^{\circ}$ journal and benefit from:}

- Convenient online submission

Rigorous peer review

- Immediate publication on acceptance

- Open access: articles freely available online

- High visibility within the field

- Retaining the copyright to your article

Submit your next manuscript at $\gg$ springeropen.com 